\title{
The Role of Judges to Protect the Apartment Buyers from The Bankruptcy of The Developer's Company
}

\author{
Lidya Sasando Parapat \\ \{lparapat5922@gmail.com\}
}

\begin{abstract}
Student of Law Doctoral Program, University of Jayabaya, Indonesia
Abstract. The purpose of this research is to analyze the role of judges in bankruptcy of apartment developer company which is caused the buyers lost their right to own the apartment unit they have paid fully and to find the solution for judges to protect the interest of the apartment buyers from the bankruptcy of developer's apartment company. This research used The Normative Legal Research with judicial formal approach by using secondary data, the result is outlined in a descriptive analytical form. The research findings are if the Judges decision only depend on the written law, the Judges decision can caused the buyers losing their right to own the apartment they have bought and paid fully, but if the Judges have the courage to explore the values which is lived in the community, the interest of buyers can be protected. Judges also have to consider that the fulfillment of the residences is a basic requirement of many people and The breach of contract from the company to fulfill the promise of delivery the unit to the buyers cannot be interpreted as a debt as bankruptcy definition of debt, because it is needed further prove which is complicated.
\end{abstract}

Keywords: bankruptcy, apartment developer, buyer.

\section{Introduction}

In the past few years, some developers apartement company have declared bankruptcy by the Judge's decision from commercial court [1], because of it, hundreds of apartment buyers lost their right to own the apartment which they have paid fully. These decisions have met requirements as determined in Law [2], but the apartment buyers felt that they were treated unfair. They protested to get legal protection because they felt, judges did not consider the interest of buyers, and the buyers were interpreted as Concurrent Creditors which are their right only will be considered if all the preference creditors have been paid from the amount of bankruptcy property sold [3]. According to The Theory of Social Dimension of Law, law has to give protection to the society, therefore judges must complete law with values which are lived in the society, so the interest of the peoples can be protected [4]. 
According to the previous studies, the pre project selling system in apartment does not full fill the principle of balance between the interest of buyers and the interest of developer [5], therefore the apartment's buyers need to be protected [6]. another previous study give solution in bankruptcy to protect creditors and debtors [7] and Separatist creditors are the creditors who get privilege treatment to get first paid from the bankruptcy asset which is the object of guarantee for their credit [8], another study analysis The Protection of Creditors based on Bankruptcy Act [9]. From the study above the writer get the conclusion, the protection of concurrent creditor in bankruptcy are very week, therefore the apartment buyers who are trying to full fill their basic need of home which are categorised as concurrent creditors has to be protected from the developer's bankruptcy.

The focus of this study are (1) to analyse the role of Judges in Bankruptcy of Developer's Apartment Company which makes buyers lost their right to own the unit which has been paid fully and (2) to find way out so Judges can role to effort protection to the interest of apartment buyers from the bankruptcy of company as developer.

\section{Method}

This study used Normative Legal Research Methodology [10] with formal juridical approach since the object to be analysed was Judge's decision related to Bankruptcy Act and other Acts related [11]. Source of data in this research was secondary data which is consist of books, journals, Judge's decisions, and other secondary data. Furthermore, the obtained data were then analysed in qualitative juridical way, by connecting to each other to find conclusion which was a unity to be stipulated in descriptive analysis.

\section{Result and Discussion}

\subsection{The Role of Judge in Bankruptcy of Apartment Developer Company Makes Buyers Lose Their Rights To own the Unit Which has been Paid Fully.}

Bankruptcy of limited company as developer of apartment started from the Judge's decision from Commercial Court which has granted proposal for Deferment of Debt Payment Obligation to the limited company as apartment developer, which has been proposed by Bank or several apartment buyers, since the limited company breach the promise to pay debt to Bank and to hand over units which has been purchased by buyers.

Based on the decision, the apartment buyers are categorized as Concurrent Creditors because the buyers have the claim to hand over the unit from developer who did not keep the promise based on agreement between company and buyers in the Sale and Purchase Binding Agreement. Judge interpreted the creditors' claim as debts, even though the value of the unit still be debated between buyers and curator (trustee).

Based on the decision of Deferment of Debt Payment Obligation, Curator Team invited Creditors and Debtor to attend the creditor meeting held by the team of curator which was chaired by the Supervisory Judge assigned in the decision. Debtor, as apartment developer, was ordered to propose reconciliation proposal to Creditors to be discussed in the meeting of creditors.

However, the reconciliation proposal was not accepted by majority of the attending Creditors which are consist of Separatist Creditor and Concurrent Creditors include the apartment buyers. As the legal consequence, Supervisory Judge must give recommendation to Judge (Panel of Judges which decide that developer is in Deferment of Debt Payment Obligation), that the developer has to be decided in the condition of bankruptcy [12]. 
As the next consequence, company asset became bankruptcy property, while apartment units which have been paid by the buyers, were still considered as the property of developer company since its land certificate was still on behalf of the company, also became bankruptcy property. Arrangement and solution of bankruptcy property were done by Curator or trustee [13] assigned by the decision of bankruptcy, in which bankruptcy property will be for sale and used for paying creditors claims on a pro-rata basis based on the levels of Creditors, namely Separatist Creditor, Preference Creditor, and Concurrent Creditor [14]. In some cases of Bankruptcy, The buyers received the share up to only $15 \%$ of total money which they paid to the developer.

Buyers complained that apartment unit was included as bankruptcy property, since they have paid unit in full and they thought that apartment has been their property. Thus, they also complained about being categorized as concurrent creditor since they should be the owner of apartment unit.

In order to fight for their right, buyers have filed a lawsuit against the company, but they took the wrong procedure because they sued curator team through common civil lawsuit. They should submit their objection based on Law of Bankruptcy [15]. but the decision of Judges would remain the same because it was investigated by the same judges, which decided Deferment of Debt Payment Obligation and Bankruptcy.

At last, buyers of the apartment unit have complained about Judge's decision [16], though Judges have decided this case based on Law of Bankruptcy and Deferment of Debt Payment Obligation.

Based on the aforementioned analysis, Judges role only applied what has been stated in the written law, in order to prove that the breach of contract of the developer obligation to buyers can be categorised as developer's debts and the apartment units are categories as bankruptcy property as defined in Bankruptcy Act.

\subsection{The effort by Judge to protect interest of Apartment buyers from the Bankruptcy of company as tenement developer}

According to the Theory of Social Dimensions of Law, the main purpose of law is to protect the interests of the peoples [17]. Marrymann \& Pérez-Perdomo, although State which embraces Civil Law System is based on the written law, as legal sources beside written law and its derivative regulation, the value which is lived in society can be made as law when it is not contrary to the written law, morality and ethics [18]. In its development, there was integration between civil law system and common law system [19]. Judges in civil law system must get authority to create law through legal interpretations based on the applicable legal provisions. According to Ter haar, Judge must be able to understand and apply the values which exist and grow in the society, so consideration and decision of Judges can be acceptable by society [20], while this decision can be considered fair and in line with structure and character of the related society.

Indonesia which embraces Civil Law System, based on the law of Judicial Power, also stipulates in law that Judge in enforcing the justice must explore these values in the society, for the interest of many people and usefulness to more people. Judges have to act progressive [21] in effort to build justice for many people.

Based on the analysis, with respect to Bankruptcy in limited company in the apartment development, aspects which can be considered by judges in protecting the interest of apartment buyers are as follows below.

Residence is the most fundamental requirement for all people. Government through Private Company (limited company) seeks to meet basic need of society by developing vertical residence. Bankruptcy act only provides exception to state corporation in which its business field relates to livelihood of many people cannot be declared Bankruptcy by Creditor [22], but excluding private limited company. According to the interest of many people and larger usefulness for many people, 
judges have the authority to interpret that this article can be able applied to the companies that build apartment in order to full fill the basic need of the peoples of residences.

Another aspect to be considered is the position of Bank as Separatist Creditor, since Bank knows that what is made as debt assurance with Insurance Right is land where the apartment is built, while its unit will be for sale to the buyers. When Developer cannot keep the promise to Bank, it is not fair if land, where building is built, is sold for the interest of Bank, while buyers of the apartment become harmed.

Based on the values in Indonesian society, buying and selling land and house are in cash and immediately transferred, which is means, after the buyers gives money for transaction, the buyers can be the owner of the apartment unit. Therefore, completion of apartment ownership certificate based on the agreement is the developer's authority, unable to eliminate the rights of the buyers of the apartment.

claims from buyers to developer is considered as the debt of developer, while it requires proof which is not simple [23]. Moreover, it still requires details about the amount when that selling price is translated into money as debt. When judges only expect to prove the existence of debt, while issue about its amount will be settled later. The lawsuit process will spend more Bankruptcy cost, and at last will harm Creditors since Bankruptcy property will be reduced for paying court fee.

Based on the reason above judges can refuse the application to state the apartment Developer Company in condition of Deferment of Debt Payment Obligation or bankruptcy, concerning the protection to the apartment buyers from the bankruptcy of apartment developer company.

\section{Conclusions}

The conclution of this studies are (1) Judges have role to determine Bankruptcy of apartment Developer Company which makes buyers lose their right to own apartment unit which has been paid fully, because the role of Judges only as the aplicator of written law. As further consequence, many buyers of apartement unit will feel that they are disadvantaged and treated unfair by the law and Judges. (2) Buyers of apartment unit can get protection from the bankruptcy oef the apartemen developer company when Judges can act progressively in facing proposal for Deferment of Debt Payment Obligation or Bankruptcy, based on values in the society, by considering decision do not only meet provision in written law, but also the interest of peoples for the benefit of peoples, in this case, the apartment buyers.

\section{Acknowledgement}

The researchers would like to thank the Chancellor of University of Jayabaya for providing the research with the title: 'The Role Of Judges To Protect The Apartment Buyers From The Bankruptcy of The Developer's Company “.

\section{References}

[1] Cases Register in Commercial court of Central Jakarta, year of 2008 until 2017.

[2] Act of Indonesian Republic Number 37 year of 2004 concerning the Bankruptcy and Deferment of Debt Payment Obligation, article 222 (3).

[3] Elyta Ras Ginting.: Bankruptcy of Law and Sience of Bankruptcy. first print. Sinar Grafika, Jakarta, 2018, hal.206.

[4] Brenden Edge Worth, Law, Modernity, Postmodemity, Legal Change in the Contracting 
State, Ashgate, Burlington, USA, 2003.

[5] Fennieka Kristianto.: The Principle of Banlance between Consumers and Developer in Binding sale and Purchase Agreement od apartement, Disertation. Law Posgraduated Doctoral Program of Indonesian University, Jakarta, 2019.

[6] Anda Setiawati.: Legal Effort concerning The Problem of Apartemen sale bound by a Binding Purchase Agreement, Disetation. Law Posgraduated Doctoral Program of Indonesian University, Jakarta, 2017.

[7] Siti Anisah.: The Protection of Creditor and Debtor Interest in Indonesian Law Bankruptcy. Disertation, Law Postgraduated Doctoral program of Indonesian University, Jakarta, 2010.

[8] Titi Tejaningsih.: The Law Protection to the Preference Creditor concerning The management and Settlement of Bankruptcy Asset. Disertation, Law Posgraduated Doctoral Program of Indonesian Moslem University, Yogyakarta, 2016.

[9] Dedi Trihartono.: Creditors Protection based on Bankruptcy Act. Sience of Law Journal, Legal Opinion, Ed. 1, Vpl. 4, tahun 2016, hal. 5. Also see Op.cit, Bankruptcy Act, articles 3 atau 127.

[10] Lili Rasyidi dan Liza Sonia Rasyidi.: Monograf : Philosophy of Sience, Research Methodology and Paper Sience of Law, Jakarta, 2011, h. 7

[11] Ronald Dworkin.: Legal Research, Spring, Daedalus, 1973, h. 250.

[12] Op.cit, Indonesian Act Number 37 of 2004, article 230 and 285 (3).

[13] Zaini Asyadie.: Commercial Law and The practice in Indonesia. PT. Raja Grafindo Persada, Jakarta, 2017, hal. 361-362.

[14] Loc.cit, Elita Ginting.

[15] Op.cit. Bankruptcy Act, article 3, 127 and 193.

[16] http://www.Property kita.com/artikel/berita/pengembang rusunami kemanggisan residence ingkar janji.

[17] Loc.cit. Brenden Edge Worth.

[18] Marrymann \& Pérez-Perdomo, The Civil Law Tradition.: An Introduction to The Legal System of Western Europe and Latin America. 2 nd Ed., Sanford University Press, California, 1985, hal. 23.

[19] Esin Orucu.: What is a Mixed legal System Exclusion or Expansion. Electronic Journal of Comparative Law, Vol. 12, No. 1, May 2008, hal. 2.

[20] Daniel S. Lev.: The Supreme Court and Adat Inheritance Law in Indonesia. The American Journal of Comparative Law, Vol. 11, No. 2, 1962, hal. 208.

[21] Ari Wibowo, ed.et.all.: Down to The Earth of Progressive Law. Aswaja Pressindo, Yogyakarta, 2013, hal. 7-9. Judges have to be brave to think progressively in order to find the solution from The Written Norms which are unable to give justice to society.

[22] Op.cit, Act Number 37 of 2004, article 2 (5).

[23] Ibid, article 8 (4) connected to article 222 (3). 